\title{
Pendekatan Pastoral terhadap Pelestarian Hutan
}

\author{
David Eko Setiawan $^{1}$; Silas Dismas Yoel Mandowen ${ }^{2}$ \\ Sekolah Tinggi Teologi Tawangmangu \\ Korepondensi: davidekosetiawan14217@gmail.com, ${ }^{1}$ dismasmandowen@gmail.com ${ }^{2}$
}

\begin{abstract}
Abstrak: Hutan merupakan habitat bagi berbagai spesies mahkluk hidup. Kelangsungan hidup mereka sangat bergantung pada pelestarian habitatnya. Namun demikian banyak hutan yang telah rusak akibat ulah manusia. Hal itu rupanya juga menimbulkan berbagai problem ekologi. Kondisi ini seharusnya mendorong gereja untuk mencari solusi yang tepat atas masalah tersebut. Melalui mandat budaya yang melekat padanya, gereja diharapkan berperan aktif dalam melestarikan hutan. Ini dapat diwujudkan melalui pendekatan pastoral yang berorientasi kepada keterlibatan jemaat dalam melestarikan hutan dari tindakan yang tidak bertanggung jawab. Penelitian ini bertujuan untuk menunjukan betapa pentingnya peran gereja dalam melestarikan hutan. Melalui sebuah pendekatan pastoral yang konkrit, gereja dapat mengejawantahkan mandat budaya tersebut. Adapun metode yang digunakan dalam penelitian ini adalah metode kepustakaan. Hasil dari penelitian ini menunjukkan bahwa berdasarkan prinsip-prinsip mandat budaya yang ada di dalam alkitab, gereja dituntut untuk terlibat aktif dalam mengatasi problem ekologi. Keterlibatan itu diwujudkan dalam pendekatan pastoral kepada jemaat dengan mengedukasi mereka tentang hakikat hutan serta melalui tindakan-tindakan praktis yang melibatkan mereka untuk melestarikan hutan sebagai habitat bagi berbagai spesias mahkluk hidup.
\end{abstract}

Kata kunci: Gereja, pelestarian, hutan, pastoral, ekologi

Abstract: Forests are habitats for various species of living things. Their survival depends heavily on the preservation of their habitat. However, many forests have been damaged by human actions. It also poses a variety of ecological problems. This condition should encourage the church to find the right solution to the problem. Through the cultural mandate attached to it, the church is expected to play an active role in preserving forests. This can be realized through a pastoral approach oriented towards the involvement of the congregation in preserving forests from irresponsible actions. This research aims to show how important the role of the church in preserving forests. Through a concrete pastoral approach, the church can answer the cultural mandate. The method used in this study is the literature method. The results of this study show that based on the principles of cultural mandate in the Bible, the church is required to be actively involved in addressing ecological problems. The involvement is manifested in the pastoral approach to the congregation by educating them about the nature of forests and through practical actions involving them to preserve forests as habitats for various species of living beings.

Keywords: Church, conservation, forest, pastoral, ecology 


\section{PENDAHULUAN}

Manusia pada dasarnya tidak dapat lepas dari alam. Bahkan agar dapat survive, manusia harus mampu menggali berbagai sumber daya alam yang ada. Namun sayangnya terdapat sebagian manusia yang salah dalam memanfaatkan berbagai sumber daya alam tersebut. Mereka mengeksploitasinya secara berlebihan, sehingga berakibat pada kerusakaan lingkungan yang begitu parah.

Hal tersebut juga terjadi kepada hutan. Hutan sebagai habitat bagi berbagai aneka ragam spesies mahkluk hidup, telah mengalami perlakukan yang tidak bertanggung jawab. Eksploitasi hutan yang berlebihan telah memunculkan berbagai problem ekologi. Salah satunya adalah Global Warming. Isu Global Warming ini sangat terkait dengan kerusakan lingkungan hutan di berbagai belahan dunia. Akibat kerusakan lingkungan tersebut, hutan sebagai paru-paru bumi tidak dapat berfungsi dengan baik sehingga berdampak pada meningkatnya kadar CO2, Metana, dan lain-lain di lapisan atmosfer yang memicu munculnya efek rumah kaca. ${ }^{1}$ Efek rumah kaca inilah yang kemudian dikaitkan dengan meningkatnya suhu bumi secara global. ${ }^{2}$ Cahyono menjelaskan bahwa Global Warming telah mengakibatkan naiknya permukaan air laut yang disebabkan mencairnya gunung-gunung es di wilayah kutub, serta memicu perubahan iklim yang ekstrim, dan juga kepunahan berbagai jenis binatang dan tumbuh-tumbuhan. ${ }^{3} \quad$ Bahkan disinyalir, munculnya berbagai penyakit baru pada manusia disebabkan oleh fenomena Global Warming yang mendorong bermigrasinya manusia dan berbagai jenis binatang akibat bencana alam. ${ }^{4}$ Menurut Cahyono, salah satu langkah konkrit untuk mengatasi dampak Global Warming adalah tetap

${ }^{1}$ Tuti Suryati, Fatliah Salim, and Titiresmi, "Pemanasan Global Dan Keanekaragaman Hayati," Teknologi Lingkungan 8, no. 1 (2007): 62-63.

${ }^{2}$ Ibid.

${ }^{3}$ Waluyo Eko Cahyono, "Pengaruh Pemanasan Global Terhadap Lingkungan Bumi," Berita Dirgantara LAPAN 16 (2015): 29.

${ }^{4}$ Mohammad Ramlan, "Pemanasan Global (Global Warming)," Jurnal Teknologi Lingkungan 3, no. 1 (2002): 31. berusaha untuk melestarikan hutan sebagai paruparu bumi agar dapat menjaga iklim global. ${ }^{5}$

Usaha di atas seharusnya menjadi tanggungjawab setiap manusia baik secara individu dan kelompok, mengingat kelestarian hutan akan berdampak langsung pada kehidupannya. Untuk itu kesadaran menjaga hutan seyogyanya menjadi fokus perhatian masyarakat saat ini.

Gereja sebagai bagian dari masyarakat, perlu berperan aktif dalam usaha pelestarian hutan. Terlebih pada diri gereja telah melekat mandat budaya yang mewajibkannya untuk mengusahakan dan mengelola alam ini secara tepat. ${ }^{6}$ Isu kerusakan lingkungan telah menjadi bagian yang tidak terpisahkan dalam ajaran gereja. Teologi lingkungan atau ekoteologi menjadi pokok bahasan yang menarik untuk dikaji dan diimplementasikan secara pastoral sebagai sebuah wujud peran gereja dalam menjaga lingkungan hidup.

Terdapat beberapa penelitian yang relevan dengan topik ini. Yuono dalam penelitiannya menunjukkan bahwa gereja perlu memperjuangkan kelestarian lingkungan hidup melalui etika Theosentris dengan menempatkan alam sebagai bagian integral cipataan Allah, sehingga keselamatan holistik harus diimplementasikan dalam perilaku yang melawan praktek-praktek perusakan lingkungan. ${ }^{7}$ Peneliti lain yang menyoroti pentingnya keterlibatan gereja terhadap pelestarian lingkungan adalah Stevanus, dalam penelitiannya ditemukan bahwa pada dasarnya usaha untuk melestarikan lingkungan dari kerusakan merupakan wujud dari mandat pembangunan atau mandat budaya dari gereja. ${ }^{8}$

${ }^{5}$ Cahyono, "Pengaruh Pemanasan Global Terhadap Lingkungan Bumi," 30.

${ }^{6}$ Daud Darmadi, "Konsep Mandat Budaya Sebagai Upaya Menjaga Kelsetarian Lingkungan Hidup,” Kaluteros: Jurnal Teologi dan Pendidikan Kristen 2, no. 1 (2020): 4-6.

${ }^{7}$ Yusup Rogo Yuono, "Melawan Etika Lingkungan Antroposentris Melalui Interpretasi Teologi Penciptaan Sebagai Landasan Bagi Pengelolaan-Pelestarian Lingkungan," FIDEI: Jurnal Teologi Sistematika dan Praktika 2, no. 1 (2019): 186-206.

${ }^{8}$ Kalis Stevanus, "Pelestarian Alam Sebagai Perwujudan Mandat Pembangunan: Suatu Kajian EtisTeologis," KURIOS: Jurnal Teologi dan Pendidikan Agama 
Pada penelitian ini, peneliti berusaha menfokuskan pada peran gereja dalam pelestarian hutan. Peran tersebut diwujudkan dalam sebuah pendekatan pastoral bagi anggota jemaat agar mereka dapat terlibat langsung dalam melestarikan hutan. Adapun research problem dalam penelitian ini adalah bagaimanakah gereja berperan secara pastoral dalam pelestarian hutan? Sedangkan tujuan dari penelitian ini adalah untuk menemukan pendekatan pastoral bagi gereja agar terlibat aktif dalam pelestarian hutan.

\section{METODE}

Metode penelitian yang dipakai oleh penulis dalam penelitian ini adalah metode library research. ${ }^{9}$ Melalui metode library research, peneliti mengumpulkan data yang bersumber dari bukubuku teks dan jurnal-jurnal ilmiah dengan membaca, menelaah, dan mencatat berbagai bahan kepustakaan yang sesuai dengan pokok bahasan, lalu disaring dan dituangkan dalam kerangka pemikiran secara teoritis. ${ }^{10}$ Sedangkan analisis yang digunakan dalam penelitian ini adalah menggunakan content analysis yang merupakan kajian yang menitikberatkan pada penafsiran dari bahan-bahan literature untuk memperoleh jawaban atas masalah penelitian.

\section{PEMBAHASAN}

\section{Pelestarian Alam dalam Konteks Ekoteologi}

"Ekologi" (ecology), merupakan kata lain dari oikos, yang terdiri dari dua kata oikos dan logos yang artinya "logika tentang rumah" atau pengetahuan tetang struktur dan dinamika dari rumah tangga dikonfigurasikan dan dijalankan. Dengan demikian "ekologi" berarti mengetahui dari dalam dinamika-dinamika yang saling berhubungan satu sama lain yang membentuk

Kristen 5, no. 2 (2019): 94-108, http://www.sttpb.ac.id/ejournal/index.php/kurios/article/view/107/70.

${ }^{9}$ Sonny Eli Zaluchu, "Metode Penelitian Di Dalam Manuskrip Jurnal Ilmiah Keagamaan,” Jurnal Teologi Berita Hidup 3, no. 2 (2021): 255-256.

${ }^{10}$ Kartini Kartono, Pengantar Metodologi Research Sosial (Bandung: Alumni Bandung, 1980), 78. kehidupan seluruh rumah tangga dan persyaratan untuk hidup bersama.

Tujuan dari ekologi itu sendiri adalah untuk menumbuhkan rasa hormat terhadap seluruh keutuhan ciptaan, dan hidup sesuai dengannya. Hal ini selaras dengan penjelasan Ernst Haeckel berikut: "dengan ekologi kita mengartikan perangkat pengetahuan yang memusatkan perhatian pada ekonomi alam sebagai penyelidikan tentang seluruh hubungan dari binatang baik dengan lingkungan organisnya maupun dengan lingkungan anorganisnya; termasuk, diatas semuanya, hubungan-hubungan yang ramah dan tidak ramah dengan binatangbinatang dan tanaman-tanaman yang dengannya dia berkontak secara langsung maupun tidak langsung." ${ }^{11}$ Secara singkat, ekologi sebagai suatu dimensi dari oikos adalah pengetahuan mengenai sistem-sistem kehidupan yang diperlukan untuk ekonomi rumah tangga. ${ }^{12}$

Dalam buku Teologi dan Ekologi karangan Celia Deane Drummond, teologi diartikan sebagai upaya yang dilakukan oleh manusia dalam penghayatan dan pemahaman akan Tuhan dan karya-Nya dalam hubungan dengan manusia. Dalam hal ini bahwa kegiatan bertelogi adalah kegiatan bersama orang percaya di dalam gereja Tuhan yang universal dan dilakukan secara kontekstual. ${ }^{13}$ Sedangkan dalam buku yang berjudul Apa Itu Teologi? karangan B. F. Drewes \& Julianus Mojou, teologi merupakan ilmu yang majemuk isinya, dimana di dalamnya terdapat beberapa bidang antara lain; Biblikal, Historika, Sistematika dan Praktika. Teologi merupakan ilmu yang berhubungan dengan spiritualitas dalam hidup yang memberi kekuatan dan pengarahan yang kemudian hendak melayani damai sejahtera dibumi. ${ }^{14}$

Istilah ekoteologi berasal dari dua kata yaitu: oikos (rumah) dan teologi. Dengan memakai kata planet sebagai rumah, Denis Edwards

${ }^{11}$ Larry L.Rasmussen, Komunitas Bumi Dan Etika Bumi (jakarta: BPK Gunung Mulia, 2010), 157-158.

${ }^{12}$ L.Rasmussen, Komunitas Bumi Dan Etika Bumi.158

${ }^{13}$ Celia Deane-Drummond, Teologi Dan Ekologi (jakarta: BPK Gunung Mulia, 2016).xii

${ }^{14}$ B. F. \& Julianus Mojou Drewes, Apa Itu Teologi? Pengantar Kedalam Ilmu Teologi (jakarta: BPK Gunung Mulia, 2017).1-2 
mendefinisikan ekoteologi sebagai "teologi tentang planet kita." Sedangkan menurut perspektif Kekristenan, ekoteologi bukan hanya sekedar sebuah kesadaran manusia dalam hal memelihara lingkungan, tetapi merupakan sebuah upaya mengkritisi tradisi kekristenan untuk membangkitkan kesadaran manusia terhadap krisis ekologi. ${ }^{15}$ Ekologi itu sendiri juga didefinisikan sebagai sebagai ilmu yang mempelajari tentang hubungan timbal balik antara mahkluk hidup dan lingkungan dimana dia berada. ${ }^{16}$ Dari sejumlah definisi diatas maka dapat disimpulkan bahwa ekoteologi dalam kekristenan adalah bentuk kesadaran manusia untuk memelihara bumi yang merupakan rumah bagi semua mahkluk hidup yang hidup didalamnya.

Dewasa ini tidak dapat disangkal oleh gereja bahwa teologi dibangun berdasarkan relasi segi tiga yang interkonektif atau saling berhubungan dan yang tidak bisa dipisahkan, yakni relasi spiritual antara Allah, manusia dan alam. Dalam relasi itulah ekoteologi lahir sebagai respon gereja. Unsur alam atau dunia merupakan hal yang penting dan menentukan bagi kontruksi teologi.

\section{Definisi Hutan}

Menurut Undang-undang nomor 41 tahun 1999, hutan didefinisikan sebagai suatu kesatuan ekosistem berupa hamparan lahan yang didominasi oleh pepohonan dalam persekutuan alam lingkungannya, yang tidak dapat dipisahkan satu dengan yang lainnya. ${ }^{17}$ Sedangkan menurut UNFCCC, hutan didefinisikan sebagai wilayah yang luasnya 0,05 1 hektar dengan tutupan kanopi minimum 10\%$30 \%$ dengan tinggi minimum $2-5$ meter. ${ }^{18}$

\footnotetext{
${ }^{15}$ Denis Edwards, Ecotheology:Science and Religion Primer (Grand Rapids: Baker, 2009).85

${ }^{16}$ Kemendikbud Badan Pengembangan dan Pembinaan Bahasa, "Kamus Besar Bahasa Indonesia Daring,"https://kbbi.kemdikbud.go.id/entri/ekologi diakses pada tanggal 10 April 2021.

${ }^{17}$ Katmoko Ari Sambodo et al., Klasifikasi HutanNon Hutan Data Alos Palsar Menggunakan Metode Random Forest, Prosiding Seminar Nasional Penginderaan Jauh 2014, n.d., 120.

${ }^{18}$ Ibid.
}

Berdasarkan penjelasan di atas maka hutan dapat diartikan sebagai habitat bagi mahkluk hidup yang di dalamnya terdapat berbagai aneka pepohonan dan binatang yang membentuk sebuah ekosistem yang saling ketergantungan.

\section{Realita Kerusakan Hutan di Indonesia}

Realita kerusakan hutan dapat ditemukan diberbagai wilayah di Indonesia. Ginoga melaporkan bahwa data kerusakan hutan lindung di Indonesia ternyata sangat memperihatikan, karena sejak tahun 1997 s/d 2002, laju kerusakan hutan lindung mencapai 10 persen per tahun. ${ }^{19}$ Bahkan total luas hutan lindung tinggal mencapai 20,7 ha dengan kerusakan yang cukup memprihatinkan. ${ }^{20} \mathrm{Hal}$ tersebut belum termasuk jenis hutan lainnya semisal hutan produksi, hutan manggrove,dan lain-lain.

Gambaran tentang berlanjutnya kerusakan hutan akibat ulah manusia yang tidak bertanggung jawab tampak dari laporan sepuluh Gubernur di Indonesia yang melaporkan kerusakan hutan di wilayah mereka masingmasing kepada Menteri Kehutanan RI pada tahun 2010. Laporan tersebut merupakan respon surat dari Menteri Kehutanan No. 95/Menhut-IV/2010 yang ditujukan kepada seluruh Gubernur di Indonesia. ${ }^{21}$ Di dalam laporan tersebut terkuak fakta berbagai kegiatan yang menyebabkan kerusakan hutan; Gubernur Aceh melaporkan temuan 49 kasus penambangan liar yang merusak hutan; Gubernur Sumatera Utara melaporkan 23 kasus perkebunan tanpa ijin; Gubernur Bangka Belitung melaporkan 87 kasus tambang liar dan kebun tanpa ijin; Gubernur Lampung melaporkan berbagai aktivitas perambahan hutan secara illegal dan 5 kasus penambangan liar; Gubernur Kalimatan Timur melaporkan

${ }^{19}$ Kirsfianti L Ginoga, Mega Lugina, and Deden Djaenudin, "Kajian Kebijakan Pengelolaan Hutan Lindung," Jurnal Penelitian Sosial dan Ekonomi Kehutanan 2, no. 2 (2005): 205.

${ }^{20} \mathrm{Ibid}$

${ }^{21}$ I Putu Gede Ardhana, "Kajian Kerusakan Sumberdaya Hutan Akibat Kegiatan Pertambangan," Ecotrophic: Journal of Environmental Science 6, no. 2 (2015): 88. 
223 aktivitas illegal yang merusak hutan; Gubernur Kalimantan Tengah melaporkan 456 kasus penambangan liar dan 964.000 ha pembukaan perkebunan tanpa ijin; Gubernur Sulawesi Tenggara melaporkan 6 kasus tambang dan perkebunan tanpa ijin; Gubernur Papua Barat melaporkan 13 kasus tambang tanpa ijin; Gubernur Papua melaporkan 7 kasus tambang tanpa ijin; Gubernur Bali melaporkan terbitnya 58 sertifikat di kawasan hutan. ${ }^{22}$

Berdasarkan laporan-laporan di atas tampak bahwa kerusakan hutan di Indonesia disebabkan oleh perilaku yang tidak bertanggung jawab dari manusia secara individu maupun kelompok. Keserakahan mereka telah berdampak pada hancurnya ekosistem hutan. Kerusakaan ini tidak hanya berdampak secara lokal namun juga global. Kehancuran hutan akan menjadi awal bagi kehancuran hidup manusia dan mahkluk hidup lainnya.

\section{Gereja dan Pelestarian Hutan}

Pada dasarnya Gereja memiliki tanggung jawab terhadap kelestarian hutan. Tanggung jawab itu terkait dengan mandat budaya yang harus ditaati olehnya. Stevanus mengatakan bahwa gereja mengemban dua mandat dari Allah, yaitu mandat penginjilan dan mandat budaya. ${ }^{23}$ Selanjutnya dia menjelaskan bahwa mandat budaya merupakan wujud tanggung jawab sosial gereja kepada masyarakat. ${ }^{24}$ Gereja tidak dapat mengelak terhadap tanggung jawab tersebut, karena hal tersebut juga merupakan bagian dari pelayanannya bagi dunia. Herlianto seperti yang dikutip oleh Darmadi menjelaskan bahwa gereja memiliki pelayanan yang holistik yaitu menjangkau manusia seutuhnya, baik tubuh, jiwa dan roh serta segala sesuatu yang terkait dengannya yaitu masalah-masalah sosial, budaya, politik, hukum dan lingkungannya. ${ }^{25}$ Disinilah peran gereja sangat dibutuhkan,

\footnotetext{
${ }^{22}$ Ibid.

${ }^{23}$ Stevanus, "Pelestarian Alam Sebagai Perwujudan Mandat Pembangunan: Suatu Kajian Etis-Teologis,” 96. ${ }^{24}$ Ibid.

${ }^{25}$ Darmadi, "Konsep Mandat Budaya Sebagai Upaya Menjaga Kelsetarian Lingkungan Hidup,” 10.
}

khususnya terkait dengan keterlibatannya mengatasi problem pelestarian hutan.

Keterlibatan aktif gereja dalam mengatasi masalah-masalah pelestarian hutan sangat dilatarbelakangi oleh teologi masing-masing aliran yang ada di dalamnya. Borong menjelaskan paling tidak terdapat tiga studi teologi yang melatarbelakangi gerakan untuk memperjuangkan kelestarian lingkungan hutan. ${ }^{26}$ Pertama, Teologi Pembebasan. Teologi ini berusaha memperjuangkan keadilan ekologis dari perilaku manusia yang semena-mena terhadap bumi. Manusia dengan IPTEKnya telah merusak dan menghancurkan bumi. Menurut Teologi Pembebasan, bumi dan segala isinya pada dasarnya memiliki harkat dan martabat serta hak untuk sejahtera dan seimbang. Bumi dan segala isinya telah ada lebih dahulu dari pada manusia. Teologi Pembebasan meyakini bahwa keadilan atas bumi dapat diwujudkan oleh anak-anak Allah sebagai perpanjangan tangan Allah. Anak-anak Allah dapat mengelola dan mengembangkan sumber-sumber alam secara bertanggung jawab kepada sang Pencipta yaitu Allah. Jika pandangan teologi ini dikaitkan dengan usaha pelestarian hutan maka penganut pandangan tersebut akan berusaha secara maksimal menjaga hutan sebagai bentuk tanggung jawabnya kepada Alah. Selain itu akan memperjuangkan kelestarian hutan dari segala bentuk "ketidakadilan" ekologis yang mewujud dalam prilaku distruktif terhadap hutan. Kedua, Teologi Ekofeminisme. Teologi ini mendasarkan pandangan pada realitas penindasan atas perempuan oleh ideologi Patriaki. Menurut Teologi Ekofeminisme, wanita dan bumi telah mendapatkan perlakukan penindasan yang sama, akibat ideology Patriakhi Sebab ideologi ini memiliki pandangan bahwa alam atau bumi sebagai realitas perempuan. Bumi tidak memiliki roh dan hanya bersifat materi sehingga menjadi inferior dihadapan laki-laki. Alam hanya sekedar alat yang dapat diekploitasi sesuka hati oleh laki-laki. Dalam mendorong keterlibatan gereja dalam masalah pelestarian hutan, Teologi Ekofeminisme memberikan usulan tentang

${ }^{26}$ Robert P. Borrong, "Kronik Ekoteologi: Berteologi Dalam Konteks Krisis Lingkungan," Stulos 17, no. 2 (2019): 187-197. 
konsep Allah sebagai Ibu, Pecinta dan Sahabat. Selain itu, teologi ini menawarkan metafor dunia sebagai tubuh Allah. Dengan metafor tersebut diharapkan dapat melahirkan tanggung jawab gereja kepada semua bagian tubuh alam serta menghindarkan penindasan terhadap perempuan dan alam. Implikasi pandangan teologi Ekofeminisme bagi para penganutnya adalah kesadaran yang tinggi untuk terus memperjuangkan hak hutan untuk lestari dengan memandangnya sebagai bentuk perlawanan akan penindasan terhadap "Ibu" mereka, yang menjadi sumber kehidupan. Ketiga, Teologi Proses. Teologi ini menawarkan pandangan bahwa Allah bukanlah penguasa mutlak (all-powerfull), melainkan Allah pengasih mutlak (all-loving). Berdasarkan pandangan ini, Teologi Proses memandang bahwa ciptaan (alam) bukanlah hasil akhir tetapi sebagai suatu proses yang masih terus berlanjut. Allah dan dunia saling mempengaruhi, pemeliharan-Nya tidak menentukan segala sesuatu, sehingga Allah bukanlah penentu segala sesuatu. Rupanya pandangan teologi baru ini sangat berorientasi kepada alam karena memiliki keyakinan Allah meresap semua alam dan hadir di tiap individu mulai dari proton hingga manusia. Disamping itu diyakini pula bahwa setiap mahkluk terikat satu dengan lainnya, sehingga manusia wajib pada nilai intristik individu dan juga kepada nilai ekologis.

Namun demikian menurut Borong, kajian teologi lingkungan tidak terbatas hanya pada tiga aliran di atas, dalam beberapa dekade terakhir studi teologi lingkungan telah mengalami perkembangan yang begitu pesat. ${ }^{27}$ Meskipun di Indonesia tergolong belum semaju di barat, namun menurut Borong, perkembangan terhadap studi teologi lingkungan atau Ekoteologi mulai tampak jelas, bahkan respon gereja-gereja dan lembaga-lembaga pendidikan teologia sangat bagus, ditandai berdirinya pusatpusat kajian yang berbasis lingkungan hidup, dan juga semakin banyaknya karya-karya ilmiah yang berkaitan dengan isu-isu ekologi. ${ }^{28}$
Perkembangan di atas merupakan angin segara bagi gereje-gereja di Indonesia untuk lebih serius berperan dalam persoalan-persoalan pelestarian hutan. Realita kerusakan hutan di Indonesia seharusnya menciptakan keprihatinan yang mendalam bagi gereja serta motivasinya untuk memperbaiki kondisi tersebut.

\section{Relasi Munculnya Ekoteologi dengan Kesadaran terhadap Pelestarian Hutan}

Ekoteologi pada dasarnya muncul akibat kritik dari beberapa pihak terhadap gereja. Borong mengungkap sejarah kritik tersebut sebagai berikut: ${ }^{29}$ Pertama, kritik awal muncul dari seorang sejarawan kebudayawan Amerika bernama Lynn White Jr, yang mengkritik kesalahan tafsir gereja terhadap Kejadian 1:2628. Tafsir yang terlalu antroposentrik telah menyebabkan kekristenan kekudusan alam dan cenderung mengeksploitasi dan merusak alam. Kedua, kritik Ian MacHarg, seorang arsitek pertamanan berkebangsaan Scotlandia. Dia berpendapat bahwa Yudaisme dan Kekristenan telah lama peduli terhadap keadilan dan belas kasihan, namun dibatasi hanya kepada antar manusia saja, sedangkan alam hanya dilihat sebagai latar belakang permainan manusia saja. Ketiga, kritik Arnold Toynbee yang menyebut bahwa Yudaisme, Kekristenan dan Islam telah menceraikan manusia dari lingkungan alamiahnya serta manusia diberi hak utk mengekspoitasi alam yang tidak lagi dianggap suci atau keramat.

Beberapa kritik di atas rupanya memicu munculnya kesadaran untuk memikirkan kembali signifikansi gereja terhadap pelestarian hutan dan lingkungannya. Menurut Borong semenjak munculnya kritik-kritik tersebut studi tentang teologi lingkungan hidup secara intensif dan masif sejak tahun 1970 tetapi terutama pada tahun 1980-an di Barat. $^{30}$ Di Indonesia, perkembangan teologi lingkungan tersebut rupanya memengaruhi pandangan gereja terhadap peran sertanya dalam pelestarian hutan. Sebagai contoh dalam Sidang Gereja PGI

\footnotetext{
${ }^{27}$ Ibid., 191.

${ }^{28}$ Ibid., 192-193.
}

\footnotetext{
${ }^{29}$ Ibid., 193-196.

${ }^{30}$ Ibid., 194.
} 
tahun 1980, ditekankan kembali pentingnya kesadaran akan lingkungan, salah satunya hutan, kepada umat dengan menghubungkan spiritualitas dengan isu-isu lingkungan hidup, dan hasilnya pada tahun 2010 muncullah program Gereja Sahabat Alam (GSA) yang memperlengkapi gereja-gereja dalam menghubungkan isu kerusakan lingkungan serta pelestarian hutan dengan iman Krsiten. ${ }^{31}$

\section{Ekoteologi Pelestarian Hutan: Sebuah Pendekatan Alkitabiah}

Keutuhan semua ciptaan merupakan suatu paradigma berteologi yang melihat kesatuan integralistik antara manusia dan seluruh unsur ciptaan lainnya sebagai sesama ciptaan. Dengan cara pandang inilah manusia dipanggil untuk menghargai dan mengasihi sesama ciptaan. Pengakuan manusia sebagai faktor utama dari kerusakan alam ini akan menjadi titik tolak. Berdasarkan pengakuan bahwa manusia adalah pelaku utama atas kerusakan alam maka secara teologis pengakuan tadi dapat diartikan sebagai ketergantungan secara total, didalamnya termasuk secara spiritual, antara manusia dan alam. Ketergantungan manusia pada alam itulah yang menjadi persoalan dasar. Relasi antara manusia dan alam merupakan suatu relasi yang tidak bisa lagi dipisahkan satu dengan yang lainnya, manusia dan alam tidak bisa dipandang sebagai subjek dan objek karena kedua-duanya merupakan subjek dari pencipta itu sendiri. Jika kita tidak memandang alam dengan keterbukaan maka kita akan bersikap seperti tuan,konsumen atau pengisap sumber daya sehingga kita tidak bisa lagi mampu memberi batas-batas, begitu sebaliknya jika kita memandang alam dengan keterbukaan maka kita akan merasa bersatu dengan semuanya. ${ }^{32}$

Kejadian pasal 1 dengan menjelaskan bahwa bumi ditata oleh Allah dengan sangat baik sebelum manusia ditempatkan didalamnya dan

\footnotetext{
${ }^{31}$ Hutagalung Risda, "Perspektif Dan Aksi AgamaAgama Di Indonesia Atasi Perubahan Iklim,” Https://www.forda-mof.org diakses pada hari Sabtu, 1 Mei 2021.

${ }^{32}$ Karel Phil Erari, Spirit Ekologi Integral (jakarta: BPK Gunung Mulia, 2017).108
}

sebelum manusia diberi perintah untuk berkuasa dan menaklukannya. Sesungguhnya perintah Allah bagi kita yang unik atas bumi itu karena akibat hubungan kita yang unik pula dengan Allah, Allah mengatur suatu tatanan bahkan hierarki, penciptaan. Sesungguhnya Allah menetapkan manusia ditengah-tengah Ia sebagai pencipta dan ciptaan lainnya, dan disatu pihak kita adalah satu kesatuan dengan alam.

Kejadian pasal 1:28 menegaskan, ketika Allah menempatkan manusia itu didalam taman, Allah berfirman kepada mereka:"Beranak cuculah dan bertambah banyak; penuhilah bumi dan taklukanlah itu, berkuasalah atas ikan-ikan dilaut dan burung-burung di udara dan atas segala binatang yang merayap dibumi." Ada dua kata Ibrani yang dipakai dalam ayat ini yang ditafsirkan sebagai hak prerogratif manusia atas ciptaan lainnya, yaitu kata רָָָּ (rada) yang artinya

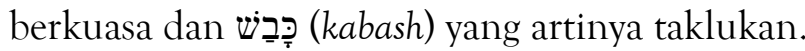

Kata rada bermakna sama dengan kekuasan seorang raja yang berkuasa atas rakyat, tawanan atau musuh yang ditaklukannya, namun kata itu juga bisa memiliki pengertian seorang raja yang mengayomi, memelihara, memberikan kesejahteraan serta keadilan. Jika manusia menyadari diri adalah sebagai mitra kerja Allah, maka kata rada mestinya dipahami dalam arti yang kedua, yaitu mengayomi, memelihara, serta memberikan kesejahteraan kepada semua ciptaan lainnya. ${ }^{33}$

Kata kabash secara harafiah berarti menaklukkan, kata itu juga dapat berarti menguasai musuh, menundukan atau menaklukan, namun demikian ayat ini tidaklah dipahami sebagai perintah untuk menghancurkan atau memperlakukan ciptan lainnya dengan semenamena. Melainkan menggaris bawahi bahwa manusia memikul tanggung jawab sebagai gambar Allah (imago dei) yaitu untuk memberlakukan kekuasaan Allah atas ciptaan lainnya. jadi kedua kata diatas mestinya dipahami sebagai mandat atau kepercayaan diberikan oleh Allah kepada manusia sebagai mitra kerja-Nya untuk membawah suatu berkat bagi segenap ciptaan lainnya. sebagai citra Allah manusia diberikan mandat untuk menguasai ciptaan lainnya, oleh

\footnotetext{
${ }^{33}$ Ibid., 442.
} 
karena itu manusia tidak seharusnya mengeksploitasi alam tetapi memanfaatkan dan memelihara serta menjaganya untuk keberlangsungan hidup. ${ }^{34}$

Diakui dan tidak diakui, telah terjadi penafsiran yang keliru terhadap teks-teks Alkitab yang berbicara mengenai hubungan antara manusia dan alam, kekeliruan yang terjadi pada penafsiran teks-teks ini secara langsung mendorong manusia untuk mengeksploitasi alam. Sehingga dalam hal ini perlu dilakukan reinterpretasi teks-teks yang berbicara mengenai hubungan antara manusia dan alam, sehingga bisa ditemukan kembali nilai-nilai mulia yang mendorong manusia memperlakukan alam sesuai dengan maksud dan tujuan yang sebenarnya. sehingga sejalan dengan pengajaran Alkitab tentang tanggung jawab manusia sebagai mitra kerjanya Allah.

Beberapa usaha untuk mereinterpretasi teksteks yang berbicara hubungan antara manusia dan alam telah dilakukan antara lain; Pertama, reinterpertasi terhadap Kejadian 1:27-31. Pada penjelasan sebelumnya tampak bahwa teks ini bukan melegalkan manusia untuk mengeksploitasi alam secara tidak bertanggungjawab, namun berdasarkan kata kata

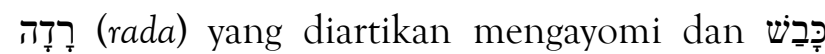
(kabash) yang diartikan sebagai menaklukkan dalam konteks wakil Allah di bumi, maka muncullah konsep mandate budaya yang mengharuskan orang percaya mengelola alam secara bertanggungjawab kepada Sang Pencipta. Reinterpertasi telah membentuk relasi yang konstruktif antara manusia dengan alam.

Kedua, reinterpertasi Mazmur 24:1-2. Teks ini harus dipahami sebagai madah pujian bagi Tuhan sebagai Raja. Namun demikian pada ayat 10, kekuasaan Raja dideklarasikan meliputi

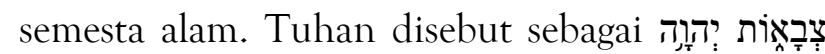
(Ibr: Yahweh Sabaoth) yang berarti Yahweh Pemilik (Ing: Host). Kata צִבְ (Sabaoth) berasal dari akar kata צָדָ (tsaba) yang dapat diartikan sebagai tentara atau pemilik. Namun berdasarkan konteks sebelumnya yaitu ayat 1-2, kata Sabaoth lebih tepat diterjemahkan sebagai pemilik, karena Dialah yang empunya bumi serta segala isinya dan yang menciptakannya. Reinterpertasi ini mengha-silkan gagasan teologis tentang hakikat kepemilikan atas alam semesta. Manusia memang telah mandapatkan mandat untuk mengelola alam, tetapi pada hakikatnya kepemilikan alam ini tetap ada pada Yahweh Sabaoth. Reinterpertasi ini memberikan gambaran yang jelas relasi antara Allah, manusia dan alam. Allah adalah pemilik, manusia adalah pengelola sedangkan alam adalah salah satu milik Allah yang harus dikelola secara bertanggung jawab.

Semua ciptaan yang mencakup hutan, tanah, air dan lainnya mempunyai fungsi yang sangat penting, yaitu sebagai: sumber kehidupan bagi manusia dan tempat tinggalnya manusia. Oleh karena itu secara teologis dapat dikatakan bahwa manusia dan seluruh ciptaan lainnya merupakan satu kesatuan yang tidak dapat dipisahkan. Manusia (Adam) dan tanah (Adamah) merupakan satu kesatuan, sebab manusia berasal dari tanah, hidup dari tanah dan kembali menjadi tanah/mati. Allah pencipta merupakan satusatunya pemilik dari semuanya, sedangkan manusia hanya memiliki hal pakai maka seharusnya manusia memakainya secara adil. Dari uraian ini dapat dilihat bahwa ciptaan lainnya dipercayakan oleh Allah kepada manusia untuk dipergunakan atau dimanfaatkan dan dipelihara, manusia boleh menggunakan semua ciptaan lainnya sebagai kebutuhannya tetapi hanya sesuai dengan kebutuhannya. Manusia tidak boleh berlaku sesukanya, manusia harus berbagi dengan sesamanya manusia dan dengan sesama ciptaan lainnya.

\section{Pendekatan Pastoral Terhadap Pelestarian Hutan}

Kerusakan lingkungan yang diakibatkan oleh aktivitas destruktif manusia, merupakan realitas yang tidak bisa diabaikan oleh gereja. Bahkan menurut Lelboy, tugas pastoral gereja yang mendesak masa kini adalah untuk menyelamatkan lingkungan yang telah rusak oleh tangan-tangan manusia yang tidak 
bertanggung jawab. ${ }^{35}$ Hal ini selaras dengan penyataan Telaumbua bahwa dengan melihat semakin seriusnya kerusakan lingkungan saat ini maka gereja wajib memberikan kontribusi langsung dalam mengatasi hal tersebut. ${ }^{36}$ Gereja tidak hadir hanya untuk melayani dirinya sendiri, tetapi diharapkan peka terhadap apa yang menjadi pergumulan masyarakat melalui berbagai karya pastoral dan sosial. Gereja perlu memiliki strategi dalam membantu mencari solusi bagi persoalan- persoalan tersebut, khususnya persoalan kerusakan hutan yang semakin serius. Agar dapat memberi sumbangsi nya maka gereja perlu melakukan pendekatan pastoral yang berorientasi pada masalah-masalah ekologi.

Pendekatan pastoral yang dimaksud dalam artikel ini adalah usaha yang dilakukan oleh gereja untuk membina warga jemaat melalui berbagai program yang dapat mengedukasi. Adapun pendekatan pastoral tersebut haruslah berorientasi kepada masalah-masalah lingkungan hidup. Gereja dapat menyusun suatu program bagi pelestarian lingkungan hutan melalui kegiatan pastoralnya. Di bawah ini terdapat beberapa usulan program yang dapat dilakukan oleh gereja sebagai langkah-langkah praktis dalam pendekatan pastoral yang berorientasikan pada ekologi.

\section{Pencanangan Pertobatan Ekologis}

Kerusakan ekologi akibat prilaku destruktif manusia mendorong adanya pertobatan dari pihaknya atas lingkungan. Pertobatan ekologis ini sangat penting karena dosa telah memengaruhi hubungan manusia dengan ciptaan. ${ }^{37}$ Smykowski menjelaskan bahwa inti dari pertobatan ekologis adalah pengakuan

\footnotetext{
${ }^{35}$ Viktoria Lelboy, "Membangun Kepedulian Pastoral Ekologi,” Jurnal REINHA 7, no. 2 (2017): 73.

${ }^{36}$ Sozawato Telaumbanua, "PAK Gereja Dalam Konteks Lingkungan Hidup Suatu Refleksi Terhadap Markus 16:15," Jurnal Shanan 4, no. 1 (2020): 45, http://library1.nida.ac.th/termpaper6/sd/2554/19755.pd f.

${ }^{37}$ Krzysztof Smykowski, "Ecological Conversion and Its Pastoral Ministry as a Stipulation for True Reconciliation," Rocznik Teologii Katolickiej 17, no. 1 (2018): 1 .
}

kebenaran tentang peran manusia di dunia dan fakta bahwa sumber daya alam itu terbatas. ${ }^{38}$ Lelboy menyatakan bahwa dalam upaya pertobatan tersebut, manusia dapat mengenal kembali siapa dirinya di hadapan lingkungan alam, dirinya sendiri, sesama, dan Allah yang telah menciptakan alam semesta. ${ }^{39}$ Pertobatan ekologis merupakan aspek penting dari rekonsiliasi antara manusia dengan alam sekitarnya. ${ }^{40}$

Berdasarkan hal di atas maka penting untuk dicanangkan pertobatan ekologis di dalam jemaat. Tujuannya agar semua warga jemaat tahu bahwa pelestarian lingkungan adalah kebutuhan mendesak demi terciptanya rekonsiliasi yang benar antara manusia dengan alam. Pencanangan ini dapat dilakukan dengan melalui tema-tema tahunan di dalam gereja yang nantinya akan mengarahkan semua pelayanan gerejawi kepada usaha pelestarian hutan dan lingkungannya. Pertobatan Ekologis menjadi semacam trigger bagi program-program selanjutnya.

\section{Edukasi Ekologis}

Smykowski menyatakan bahwa misi gereja bukan sekedar menentukan kondisi yang diperlukan oleh manusia bagi terciptanya sebuah rekonsiliasi, namun gereja juga wajib membimbing manusia kepada pelayanan rekonsiliasi dengan Allah, manusia dan alam sekiranya tersebut. ${ }^{41}$ Artinya, gereja secara pastoral wajib memberikan bimbingan dalam bentuk pengajaran kepada warga gereja agar mereka memahami relasi yang benar dengan Allah, sesama, dirinya sendiri dan lingkungannya. Dalam kaitannya dengan hutan sebagai salah satu bagian dari alam, perlu adanya edukasi secara mendalam kepada mereka, agar timbul kepekaan atas problematika ekologis yang sedang terjadi.

\footnotetext{
${ }^{38}$ Ibid.

${ }^{39}$ Lelboy, "Membangun Kepedulian Pastoral Ekologi," 88.

${ }^{40}$ Smykowski, "Ecological Conversion and Its Pastoral Ministry as a Stipulation for True Reconciliation," 2.
} 
Ayres mengutip Orr mengusulkan jenis eduksi ekologis yang transformati bagi gereja, dimana di dalamnya mengarahkan orang percaya untuk memahami dan mengenal dirinya sebagai stewardship atas sumber-sumber alam dan bukan menempatkan dirinya sebagai penguasa atasnya. ${ }^{42}$ Untuk mencapainya diperlukan tematema yang dapat menginspirasi warga jemaat untuk peka terhadap persoalan lingkungan.

Dalam menyusun tema-tema tersebut perlu mempertimbangkan beberapa prinsip berikut: ${ }^{43}$ Pertama, Allah adalah pencipta dan pemelihara segala ciptaan-Nya (Kej. 1:1-31). Sebagai pencipta Allah dipahami sebagai causa prima. Sedangkan sebagai pemelihara, Allah adalah penopang dari segala yang Ia ciptakan (Ibr. 1:3). Bahkan melalui pemeliharaan-Nya, Allah menunjukkan konsistensi-Nya dalam mengasihi segala ciptaanNya. Prinsip ini memberikan dorongan kepada setiap warga jemaat untuk menghargai ciptaan Allah sebagai karya-Nya yang agung. Terbukti dari pemeliharaan Allah dalam menopang segala ciptaan-Nya hingga kini. Keterlibatan umat Allah dalam memelihara lingkungan dari kerusakan merupakan wujud pelayanan mereka kepada Allah Sang Pencipta dan Pemelihara. Dan sebaliknya, tindakan destruktif atas alam menunjukkan ketidakhormatan atas pribadi Allah atas karya-Nya.

Kedua, manusia merupakan citra dan mitra Allah bagi dan dalam dunia seutuhnya (Kej. 1:27-28; 2:1-25). Berdasarkan prinsip tersebut tampak bahwa manusia tidak dapat mengelak akan tanggung jawabnya terhadap kelestarian lingkungannya. Sebagai citra Allah di dalam dunia, manusia berkewajiban merefelksikan jati diri Allah sebagai pencipta dan pemelihara atas segela ciptaan-Nya. Jika Allah masih menopang alam semesta hingga saat ini maka manusia wajib melakukan hal yang sama sebagai wujud refleksi dari citra Allah di bumi. Dan sebagai mitra Allah, manusia berkewajiban bekerjasama

${ }^{42}$ Jennifer R. Ayres, "Cultivating the "Unquiet Heart': Ecology, Education, and Christian Faith,” Theology Today 74, no. 1 (2017): 63.

${ }^{43}$ Marthinus Ngabalin, "Ekoteologi: Tinjauan Teologi Terhadap Keselamatan Lingkungan Hidup," CARAKA: Jurnal Teologi Biblika dan Praktika 1, no. 2 (2020): 118-134. dengan Allah dalam melestarikan lingkungan bumi serta segala isinya. Praktek distruktif terhadap alam merupakan bentuk ketidak selarasan manusia sebagai mitra Allah di bumi. Prinsip ini mendorong warga jemaat untuk menyadari relasinya dengan alam dan lingkungannya lingkungannya. Setiap anggota jemaat merupakan citra dan mitra Allah di bumi untuk menjaga dan memelihara lingkungannya. Prinsip ini dapat menjadi acuan pendekatan pastoral terhadap warga jemaat agar memunculkan rasa tanggung jawab terhadap pelestarian alam.

Ketiga, alam adalah miliki Allah (Mzm. 24:1. Alam sebagai salah satu ciptaan Allah, pada hakikatnya adalah milik Allah, sedangkan manusia diciptakan untuk mengusahakannya. Mandat penguasaan alam yang diberikan Allah kepada manusia tetap menjadi bagian yang utuh dengan mandat pemeliharaannya. Rasa hormat manusia kepada Allah sang pencipta dan pemiliki alam, diwujudkan dalam prilaku hormat atas alam dan lingkungannya. Hal ini merupakan refleksi rasa hormat manusia terhadap Sang Penguasa alam semesta. Prinsip tersebut mendorong warga jemaat untuk mengakui alam sebagai sesama ciptaan yang harus dikelola dengan rasa hormat kepada Allah.

Agar program edukasi ekologis ini berjalan dengan baik di dalam warga jemaat maka diperlukan beberapa langkah konkrit yang menyertainya, antara lain: ${ }^{44}$ Pertama, pelayanan gerejawi yang berbasis pelestarian lingkungan. Kedua, khotbah yang berbasis tema-tema ekologi sebagai wujud edukasi transformatif bagi pemahaman warga jemaat terhadap pentingnya pelestarian lingkungan. Ketiga, penyususunan startegi dan metode pelayanan hamba Tuhan yang berbasis pelestarian lingkungan.

\section{Membangun Komunitas Ekologis}

Pada dasarnya gereja merupakan komunitas yang relevan dengan konteks dimana ia berada. ${ }^{45}$

\footnotetext{
${ }^{44}$ Darmadi, "Konsep Mandat Budaya Sebagai Upaya Menjaga Kelsetarian Lingkungan Hidup,” 11.

${ }^{45}$ Crowther Danny, "Komunitas Yang Relevan," in Jemaat Misioner, ed. Yoel M. Indrasmoro et al. (Jakarta: Yayasan Komunikasi Bina Kasih, 2011), 285.
} 
Gereja sebagai pembawa berita Injil harus mampu mengkontekstualisaikan berita tersebut di tengah-tengah masyarakat agar pesan yang disampaikan tetap relevan dan mudah untuk dimengerti. ${ }^{46}$ Melalui kehidupan gereja yang real maka pesan Injil sebagai kabar sukacita akan tampak jelas. Untuk mewujudkan hal tersebut maka perlu adanya bimbingan kepada umat Allah agar dapat mengejawantahkan Injil dalam praktek hidup sehari-hari.

Dalam kaitannya dengan pelestarian lingkungan, gereja dapat membentuk komunitaskomunitas peduli lingkungan di dalam jemaat. Komunitas ekologis ini merupakan perwujudan dari Injil (baca: Berita Sukacita) bagi alam. Komunitas tersebut dapat menjadi tempat warga jemaat terlibat aktif dalam pelestarian lingkungan, khususnya hutan. Di dalam komunitas ini, dapat dilakukan pendekatan pastoral kepada warga jemaat melalui kegiatankegiatan yang berbasis lingkungan antara lain: ${ }^{47}$ Reboisasi pada hutan-hutan yang rusak akibat penebangan liar, pengelolaan sampah organik dan anorganik di sekitar wilayah hutan, penangkaran aneka hayati yang mulai punah, promosi kegiatan sadar lingkungan hutan melalui media sosial, dan lain-lain

\section{KESIMPULAN}

Bahaya yang dihadapi oleh manusia saat ini bukan lagi hanya datangnya dari luar melainkan dalam dirinya sendiri, dimana mereka tidak dapat lagi mengendalikan diri sehingga cenderung melakukan eksploitasi besar-besaran terhadap hutan. Keserakahan manusia dan pengeksploitasian tersebut telah mengakibatkan masalah ekologis. Hutan menjadi rusak serta berdampak pada lingkungan sekitarnya.

Pada dasarnya semua mahkluk hidup mendambakan lingkungan yang baik dan indah, dimana lingkungan tersebut dapat menjadi

${ }^{46}$ David Eko Setiawan, "Menjembatani Injil Dan Budaya Dalam Misi Melalui Metode Kontektualisasi," Fidei: Jurnal Teologi Sistematika dan Praktika 3, no. 2 (2020): 178.

${ }^{47}$ Telaumbanua, "PAK Gereja Dalam Konteks Lingkungan Hidup Suatu Refleksi Terhadap Markus 16:15," 51-53. tempat hidup yang layak bagi mereka. Namun hal tersebut seakan-akan hanya menjadi sebuah impian saja karena telah dirusak oleh mereka sendiri. Lingkungan yang rusak akibat ulah manusia mengeksploitasi hutan secara salah seharusnya menjadi perhatian bagi setiap pihak.

Untuk menanggapi permasalah tersebut, gereja seharusnya terlibat aktif dalam menangani masalah ekologi tersebut. Peran gereja dapat diwujudkan melalui pendekatan pastoral kepada segenap warga jemaat yang ada di sekitar wilayah hutan. Pendampingan tersebut dapat berwujud pencanangan pertobatan ekologis, edukasi ekologis dan pembentukan komunitas ekologis. Tujuan pendampingan tersebut agar warga jemaat dapat peka dan terlibat akitif dalam pelestarian hutan dan lingkungannya. Hutan merupakan sumber kehidupan bagi manusia dan mahkluk hidup lainnya, maka dari itu selayaknya hutan dan lingkungannya dilestarikan oleh setiap pihak.

\section{KEPUSTAKAAN}

Ardhana, I Putu Gede. "Kajian Kerusakan Sumberdaya Hutan Akibat Kegiatan Pertambangan." Ecotrophic: Journal of Environmental Science 6, no. 2 (2015): 8793.

Ayres, Jennifer R. "Cultivating the 'Unquiet Heart': Ecology, Education, and Christian Faith." Theology Today 74, no. 1 (2017): 5765.

Borrong, Robert P. "Kronik Ekoteologi: Berteologi Dalam Konteks Krisis Lingkungan." Stulos 17, no. 2 (2019): 185212.

Cahyono, Waluyo Eko. "Pengaruh Pemanasan Global Terhadap Lingkungan Bumi." Berita Dirgantara LAPAN 16 (2015): 28-31.

Danny, Crowther. "Komunitas Yang Relevan."

In Jemaat Misioner, edited by Yoel M. Indrasmoro, John Ruck, M.S.M Situmorang, and Amelia Situmorang Wenas, 507. Jakarta: Yayasan Komunikasi Bina Kasih, 2011.

Darmadi, Daud. "Konsep Mandat Budaya Sebagai Upaya Menjaga Kelsetarian 
Lingkungan Hidup.” Kaluteros: Jurnal Teologi dan Pendidikan Kristen 2, no. 1 (2020): 1-16.

Deane-Drummond, Celia. Teologi Dan Ekologi. jakarta: BPK Gunung Mulia, 2016.

Drewes, B. F. \& Julianus Mojou. Apa Itu Teologi? Pengantar Kedalam Ilmu Teologi. jakarta: BPK Gunung Mulia, 2017.

Edwards, Denis. Ecotheology:Science and Religion Primer. Grand Rapids: Baker, 2009.

Erari, Karel Phil. Spirit Ekologi Integral. jakarta: BPK Gunung Mulia, 2017.

Kartono, Kartini. Pengantar Metodologi Research Sosial. Bandung: Alumni Bandung, 1980.

Kemendikbud Badan Pengembangan dan Pembinaan Bahasa. "Kamus Besar Bahasa Indonesia Daring.” Last modified 2016. https://kbbi.kemdikbud.go.id/entri/pand emi.

L.Rasmussen, Larry. Komunitas Bumi Dan Etika Bumi. jakarta: BPK Gunung Mulia, 2010.

L Ginoga, Kirsfianti, Mega Lugina, and Deden Djaenudin. "Kajian Kebijakan Pengelolaan Hutan Lindung." Jurnal Penelitian Sosial dan Ekonomi Kehutanan 2, no. 2 (2005): 169194.

Lelboy, Viktoria. "Membangun Kepedulian Pastoral Ekologi." Jurnal REINHA 7, no. 2 (2017): 73-88.

Mohammad Ramlan. "Pemanasan Global (Global Warming).” Jurnal Teknologi Lingkungan 3, no. 1 (2002): 30-32.

Ngabalin, Marthinus. "Ekoteologi : Tinjauan Teologi Terhadap Keselamatan Lingkungan Hidup." CARAKA: Jurnal Teologi Biblika dan Praktika 1, no. 2 (2020): 118-134.

Risda, Hutagalung. "Perspektif Dan Aksi AgamaAgama Di Indonesia Atasi Perubahan Iklim." Https://www.forda-mof.org.

Sambodo, Katmoko Ari, Mulia Inda Rahayu, Novie Indriasari, and M Natsir. Klasifikasi Hutan-Non Hutan Data Alos Palsar Menggunakan Metode Random Forest. Prosiding Seminar Nasional Penginderaan Jauh 2014, n.d.

Setiawan, David Eko. "Menjembatani Injil Dan Budaya Dalam Misi Melalui Metode
Kontektualisasi." Fidei: Jurnal Teologi Sistematika dan Praktika 3, no. 2 (2020): 160-180.

Smykowski, Krzysztof. "Ecological Conversion and Its Pastoral Ministry as a Stipulation for True Reconciliation." Rocznik Teologii Katolickiej 17, no. 1 (2018): 7-17.

Stevanus, Kalis. "Pelestarian Alam Sebagai Perwujudan Mandat Pembangunan: Suatu Kajian Etis-Teologis.” KURIOS: Jurnal Teologi dan Pendidikan Agama Kristen 5, no. 2 (2019): 94-108. http://www.sttpb.ac.id/ e-journal/index.php/kurios/article/view/ $107 / 70$.

Suryati, Tuti, Fatliah Salim, and Titiresmi. "Pemanasan Global Dan Keanekaragaman Hayati." Teknologi Lingkungan 8, no. 1 (2007): 61-68.

Telaumbanua, Sozawato. "PAK Gereja Dalam Konteks Lingkungan Hidup Suatu Refleksi Terhadap Markus 16:15." Jurnal Shanan 4, no. 1 (2020): 41-56. http://library1.nida. ac.th/termpaper6/sd/2554/19755.pdf.

Yuono, Yusup Rogo. "Melawan Etika Lingkungan Antroposentris Melalui Interpretasi Teologi Penciptaan Sebagai Landasan Bagi Pengelolaan-Pelestarian Lingkungan.” FIDEI: Jurnal Teologi Sistematika dan Praktika 2, no. 1 (2019): 186-206.

Zaluchu, Sonny Eli. "Metode Penelitian Di Dalam Manuskrip Jurnal Ilmiah Keagamaan." Jurnal Teologi Berita Hidup 3, no. 2 (2021): 6.

Statistik, Biro Pusat. "Nikah, Talak Dan Cerai, Serta Rujuk, 2007-2016,” 2020. https://www.bps.go.id/linkTableDinamis/ view/id/893.

Tanner, J. Paul. "The History of Interpretation of the Song of Songs." Biblioteca Sacra 154:163 (1997).

- . "The Message of the Song of Songs." Biblioteca Sacra 154:163 (1997).

Tiwery Yudit, Weldemina. "Desire of Love: Menafsir Kidung Agung 7:10-8:4.” GEMA TEOLOGI 39, no. 1 (2015): 1-14.

Trible, Phyllis. God and The Rhetoric of Sexuality. London: SCM Press, 1992. 
Trucksess, Kurt. Solomon on Sex. Spirit Lake: Faith Church, 2012.

VI, Paus Paulus. "Humanae Vitae: Encycal on the Right Ordering of Procreation Children.” Acta Apostolociae Sedis 6012 (1968).

Vos, Charles F. Pfeiffer dan Howard F. The Wyclife Historical Geography of Bible Lands. Chicago: Moody Publishers, 1967.

Waltke, Bruce K. An Introduction To Biblical Hebrew Syntax. Indiana: Eisenbrauns, 1990.

Warren, Rick. Rick Warren's Bible Study Methods. Michigan: Zondervan, 2006.

Watson, W.G.E. Classical Hebrew Poetry: A Guide to Its Techniques. Sheffield: Sheffield Academic Press, 1984.

Wijaya, Agetta Putri. "Tafsir Alegoris, Konstruksi Teologis, Dan Unsur Erotis Dalam Kitab Kidung Agung." Indonesian Journal of Theology 4, no. 2 (2016): 237-56.

Wiseman, G. Lloyd Carr \& D. J. The Song of Solomon: An Introduction and Commentary. Downers Grove: Inter-Varsity Press, 1984. 